\title{
Seaweed Investment as Application in Development of Minapolitan Area
}

\author{
Caroline \\ Faculty of Economic, Universitas Sultan Fatah Demak \\ Jl. Sultan Fatah 83 Demak 59516, Jawa Tengah, Indonesia, Phone: +62-291-681024 \\ E-mail address: carolinehamboro@yahoo.com
}

\begin{abstract}
Consequences of regional autonomy is not easy, this is because a required area should look for alternative sources of financing regional. One of the sources of financing in the Brebes district is the development of seaweed cultivation to be exported to other countries. The calculations show that the investment in seaweed farming is feasible to be developed because of the many advantages gained than seaweed farming. The first advantage of the presence of a source of income for local communities and Brebes district, opening job opportunities broadly, to develop products made from seaweed such as cosmetics, pharmaceuticals, herbs, jelly, and so forth.
\end{abstract}

Keywords: investment, seaweed farming, minapolitan, income communities

JEL Classification Codes:E2,R1,R5

\section{Investasi Rumput Laut Sebagai Aplikasi Pengembangan Kawasan Minapolitan}

\begin{abstract}
Abstrak
Konsekuensi otonomi daerah sangatlah tidak mudah, mengingat suatu daerah dituntut harus mencari alternatif sumber pembiayaan daerahnya. Salah satu sumber pembiayaan di Kabupaten Brebes adalah pengembangan budidaya rumput laut yang akan diekspor ke negara lain. Hasil perhitungan menunjukkan bahwa investasi pada budidaya rumput laut layak untuk dikembangkan karena keuntungan yang banyak diperoleh daripada budidaya rumput laut. Keuntungan pertama adanya sumber pendapatan bagi masyarakat setempat dan Kabupaten Brebes, membuka kesempatan kerja yang luas, dapat mengembangkan produk yang berbahan rumput laut seperti kosmetik, obat-obatan, jamu, agar-agar, jelly dan lain sebagainya.
\end{abstract}

Kata kunci: investasi, budidaya rumput laut, minapolitan, pendapatan masyarakat Kode Klasifikasi JEL:E2, R1, R5 


\section{Pendahuluan}

Pelaksanaan otonomi daerah membawa konsekuensi agar masing-masing daerah berlombalomba mencari sumber pembiayaan daerahnya. Suatu daerah yang tidak mampu membiayai sumber pembiayaan daerah akan di merger (digabungkan) atau dihapuskan. Bahkan tidak menutup suatu daerah dapat juga dimekarkan wilayahnya.

Kabupaten Brebes merupakan salah satu Kabupaten di Jawa Tengah yang melaksanakan otonomi daerahnya. Kabupaten Brebes mempunyai luas wilayah $166.019,07$ ha yang mencakup 17 Kecamatan, 292 Desa dan 5 Kelurahan. Berdasarkan bentuk permukaan wilayah, Kabupaten Brebes terbagi dalam 3 (tiga) kategori wilayah yakni dataran pantai di bagian utara, landai sampai bergelombang di bagian tengah dan berbukit sampai bergunung di bagian selatan dengan jumlah penduduk pada tahun 2006 sebanyak 1.736 .401 jiwa.

Berkaitan dengan kegiatan investasi, dapat diuraikan bahwa kegiatan investasi merupakan faktor yang sangat penting untuk menggerakkan ekonomi daerah. Makin besar arus masuk investasi dapat menciptakan peluang munculnya kegiatan-kegiatan usaha yang lain. Implikasinya antara lain meningkatnya kesempatan kerja dan peluang terjadinya peningkatan PAD. Dengan kata lain bahwa investasi dapat menimbulkan multiplier effect bagi kemajuan ekonomi daerah. Manfaat penanaman modal langsung (direct investment) selain karena sifatnya jangka panjang juga terjadi adanya tranformasi modal, penciptaan lapangan kerja, transfer teknologi, akses ke pasar dunia dan transfer kemampuan manajerial.

Dalam rangka pengembangan dan peningkatan investasi, pemerintah Kabupaten Brebes telah melakukan berbagai upaya, di antaranya adalah dengan peningkatan program promosi dan pengembangan kerjasama regional, nasional maupun internasional. Dengan semakin mantap akan dikembangkannya Kabupaten Brebes sebagai kota bisnis melalui kegiatan perdagangan, industri dan pariwisata berskala nasional dan internasional, maka pemahaman yang lebih menyeluruh tentang arti penting pencapaian tujuan pembangunan daerah perlu dikembangkan dan dijadikan dasar pengembangan investasi.

Komitmen Pemerintah Daerah Kabupaten Brebes untuk memperbaiki iklim investasi merupakan faktor penentu bagi kesinambungan pertumbuhan ekonomi selanjutnya. Langkah nyata perbaikan iklim investasi sangat diperlukan guna menjaga persepsi positif pelaku ekonomi dan usaha. Secara umum arah kebijakan pembangunan ekonomi adalah meningkatkan taraf hidup rakyat, memperluas lapangan kerja, meratakan pembagian pendapatan masyarakat serta mendorong agar pertumbuhan ekonomi selalu berkelanjutan. Tujuan yang ingin dicapai ini mengandung konsekuensi bahwa penggalian potensi-potensi yang terdapat di daerah senantiasa dilakukan untuk mendorong tumbuhnya investasi baru yang dapat menstimulus perekonomian ke arah yang lebih maju.

Pengertian Kawasan Minapolitan. Minapolitan terdiri dari kata mina dan politan (polis). Mina berarti ikan dan politan berarti kota, sehingga minapolitan dapat diartikan sebagai kota perikanan atau kota di daerah lahan perikanan atau perikanan di daerah kota. Dalam pedoman pengembangan kawasan minapolitan disebutkan bahwa kawasan minapoltan adalah kota perikanan yang tumbuh dan berkembang karena berjalannya sistem dan usaha perikanan serta mampu melayani, mendorong, menarik, menghela kegiatan pembangunan ekonomi daerah sekitarnya.

Menurut UU Penataan Ruang No 26/2007, didefinisikan sebagai kawasan yang terdiri atas satu atau lebih pusat kegiatan pada wilayah perdesaan sebagai sistem produksi pertanian dan pengelolaan sumberdaya alam tertentu yang ditunjukkan oleh adanya keterkaitan fungsional dan hierarki keruangan satuan sistem permukiman dan sistem agribisnis. Kawasan Minapolitan berdasarkan turunan kawasan Agropolitan: adalah kawasan yang terdiri atas satu atau lebih pusat kegiatan pada wilayah perdesaan sebagai sistem produksi perikanan dan pengeloaan sumberdaya alam tertentu yang ditunjukkan oleh adanya keterkaitan fungsional dan hierarki keruangan satuan sistem permukiman dan sistem minabisnis.

Kawasan minapolitan (berdasarkan turun- 
an dari kawasan agropolitan) adalah kawasan yang terdiri atas satu atau lebih pusat kegiatan pada wilayah perdesaan sebagai sistem produksi perikanan dan pengelolaan sumberdaya alam tertentu yang ditunjukkan oleh adanya keterkaitan fungsional dari hierarki keruangan satuan sistem pemukiman dan sistem minabisis. Minapolitan/agropolitan menurut Friedman dan Douglass (1985) adalah aktivitas pembangunan yang terkonsentrasi di wilayah pedesaan denga jumlah penduduk antara 50.000 jiwa sampai dengan 150.000 jiwa. Kawasan Minapolitan dapat terbentuk berdasarkan 2 (dua karakter) yang berbeda, yaitu kawasan minapolitan berbasis pada perikanan laut dan perikanan darat. Kawasan perikanan laut merupakan ekosistim perikanan pada wilayah lautan luas semuanya adalah alami, sehingga ikan yang hidup berkembang di dalamnya juga sudah tersedia dari alam, diluar pengaruh tangan manusia. Sedangkan kawasan perikanan darat memiliki ekosistem berbeda dari perikanan laut. Kawasan perikanan darat kebanyakan adalah buatan, sedemikian hingga dalam proses budidayanya sangat bergantung pada tangan-tangan manusia yang mengelola dan mengembangkannya.

Ciri-Ciri Kawasan Minapolitan. Secara teknis, sebuah kawasan dikatakan sebagai kawasan minapolitan apabila memiliki ciri-ciri antara lain:

a) Sebagian besar masyarakat di kawasan memperoleh pendapatan dari kegiatan perikanan;

b) Sebagian besar kegiatan di kawasan didominasi oleh kegiatan perikanan termasuk di dalamnya usaha pengolahan hasil, perdagangan hasil-hasil perikanan, perdagangan agribisnis hulu (sarana produksi dan modal), agrowisata dan jasa pelayanan;

c) Hubungan antara pusat pertumbuhan dengan hinterland bersifat timbal balik yang harmonis dan saling membutuhkan. Dimana pada kawasan sentra produksi mengembangkan usaha budidaya (on farm)dan pengolahan hasil skala rumah tangga (off farm), sedangkan kota menyediakan fasilititas untuk berkembangnya usaha budidaya dan minabisnis yaitu penyediaan sarana perikanan, permodalan, teknologi, informasi pengolahan hasil dan penampungan (pemasaran) hasil produksi perikanan.

d) Kehidupan masyarakat di Kawasan Minapolitan mirip dengan suasana kota karena keadaan sarana yang ada di Kawasan Minapolitan tidak jauh beda dengan kota.

Persyaratan Kawasan Minapolitan. Persyaratan suatu kawasan disebut sebagai Kawasan Minapolitan adalah:

a) Memiliki sumberdaya lahan/perairan yang sesuai untuk pengembangan komoditas perikanan yang dapat dipasarkan atau telah mempunyai pasar (komoditas ungulan), serta berpotensi atau telah berkembang diversifikasi usaha dari komoditas unggulannya. Pengembangan kawasan tersebut tidak saja menyangkut kegiatan budidaya perikanan (on farm) tetapi juga kegiatan off farmnya, yaitu mulai dari pengadaan sarana dan prasarana perikanan (benih, pakan, obat-obatan), kegiatan pengolahan hasil perikanan sampai dengan pemasaran hasil perikanan serta kegiatan penunang (pasar industri, industri pengolahan, minawisata, dan sebagainya);

b) Memiliki berbagai sarana dan prasarana agribisnis yang memadai untuk mendukung pengembangan sistem dan usaha agribisnis perikanan, yaitu:

(1) Pasar, baik pasar untuk hasil-hasil perikanan, pasar sarana perikanan, alat dan mesin perikanan, maupun pasar jasa pelayanan termasuk pasar lelang, gudang tempat penyimpanan (cold storage) dan prossesing hasil perikanan sebelum dipasarkan;

(2) Lembaga keuangan (perbankan dan non perbankan) sebagai sumber modal untuk kegiatan minabisnis;

(3) Memiliki kelembagaan pembudidayaan ikan (kelompok, UPP) yang dinamis dan terbuka pada inovasi baru, yang harus berfungsi pula sebagai Sentra Pembelajaran dan Pengembangan Minabisnis (SPPM);

(4) Balai Benih Ikan (BBI) Unit Pembenihan Rakyat (UPR) dan sebagainya yang berfungsi sebagai penyuplai induk dan penyedia benih untuk kelangsungan kegiatan budidaya ikan;

(5) Penyululan dan bimbingan teknologi minabisnis untuk mengembangkan teknologi tepat guna yang cocok untuk daerah Kawasan Minapolitan; 
(6) Jaringan jalan yang memadai dan aksesibilitas dengan daerah lainnya serta sarana irigasi, yang kesemuanya untuk mendukung usaha perikanan yang efisien.

(7) Memiliki sarana prasarana umum yang memadai yaitu jaringan transportasi, jaringan listrik, telekomunikasi, air bersih;

(8) Memiliki sarana dan prasarana kesejahteraan sosial/masyarakat yang memadai seperti pendidikan, kesehatan, kesenian, rekreasi, perpustakaan, swalayan dan lainya.

(9) Kelestarian lingkungan hidup baik kelestarian sumberdaya alam, kelestarian sosial budaya maupun keharmonisan hubungan kota desa terjamin.

Batasan Kawasan Minapolitan. Batasan suatu Kawasan Minapolitan tidak ditentukan oleh batasan administratif pemerintah (desa/ kelurahan, kecamatan, kabupaten dan sebagainya) tetapi lebih ditentukan dengan memperhatikan economic of scale dan economic of scope. Karena itu, penetapan Kawasan Minapolitan hendaknya dirancang secara lokal dengan memperhatikan realitas perkembangan Minabisnis yang ada di setiap daerah. Dengan demikian bentuk dan luasan Kawasan Minapolitan dapat meliputi suatu wilayah desa/kelurahan atau kecamatan atau beberapa kecamatan dalam kabupaten/kota atau dapat juga meliputi wilayah yang dapat menembus wilayah kabupaten/kota lain yang berbatasan. Kotanya dapat berupa kota desa atau kota nagari atau kota kecamatan atau kota kecil atau kota menengah.

Analisis Pengembangan Kawasan. Analisis yang dilakukan dalam pengembangan kawasan minapolitan dalam kegiatan Pemetaan Kawasan Budidaya dan Program Minapolitan Kabupaten Brebes meliputi beberapa analisis. Secara makro analisis ini dilakukan untuk memahami kondisi unsur-unsur pembentuk ruang serta hubungan sebab akibat terbentuknya kondisi ruang wilayah, dengan memperhatikan kebijaksanaan pembangunan wilayah yang ada. Analisis yang dilakukan meliputi analisis terhadap kondisi sekarang dan kecenderungan di masa yang akan dating. Berikut merupakan uraian dari masing-masing analisis yang digunakan dalam kegiatan Pemetaan Kawasan Budidaya dan Program Minapolitan
Kabupaten Brebes

Analisis Kebijakan dan Strategi Pengembangan Kabupaten Brebes. Analisis ini dilakukan untuk memahami arahan kebijakan pengembangan kawasan dan kedudukannya dalam perspektif kebijakan pembangunan Kabupaten Brebes, serta untuk mengantisipasi dan mengakomodasi program-program pembangunan sektoral yang akan dilaksanakan. Oleh karena itu, selain dilakukan pengkajian terhadap tujuan dan sasaran pengembangan kawasan perikanan budidaya (minapoliatan) Kabupaten Brebes juga dilakukan pengkajian terhadap Rencana Tata Ruang Wilayah (RTRW) Kabupaten Brebes serta program-program sektoral untuk melihat peranan kawasan dalam pembentukan pola dan struktur ruang Kabupaten Brebes. Berikut merupakan kajian analisis kebijakan dan strategi pengembangan Kabupaten Brebes yang dilihat dari RTRW Kabupaten Brebes dan Kebijakan sektoral pengembangan perikanan Kabupaten Brebes.

Kajian Kebijakan RTRW Kabupaten Brebes. Berdasarkan kajian terhadap arahan RTRW Kabupaten Brebes dapat dirumuskan beberapa substansi kebijakan dan arahan yang berpengaruh dalam pembentukan pola dan struktur ruang pengembangan Kawasan Minapolitan Kabupaten Brebes yang terdapat di wilayah Kecamatan Losari, Tanjung, Bulakamba, Wanasari dan Brebes, yaitu :

a) Kebijakan, strategi dan arahan pengembangan struktur ruang

Arahan pengembangan struktur ruang (hirarki pusat pelayanan) yang terdapat di wilayah pengembangan minapolitan (Kecamatan Losari, Tanjung, Bulakamba, Wanasari dan Brebes) adalah:

Kecamatan Losari, Bulakamba, dan Wanasari termasuk arahan hirarki pusat pelayanan Kota Pusat Pengembangan III khususnya pada kawasan perkotaan Losari, Bulakamba, dan Wanasari. Kota Pusat pengembangan III direncanakan memiliki skala pelayanan kecamatan. Jenis fasilitas dan prasarana yang dilokasikan di kawasan perkotaan ini dirancang untuk memiliki pelayanan kecamatan.

Kecamatan Brebes termasuk kedalam arahan hirarki pusat pelayanan Kota Pusat Pengembangan Utama khususnya pada kawasan 
perkotaan Brebes. Kota Pusat Pengembangan Utama direncanakan memiliki skala pelayanan regional. Jenis fasilitas dan prasarana yang dilokasikan di kawasan perkotaan ini dirancang untuk memiliki pelayanan regional.

Kecamatan Tanjung termasuk kedalam arahan hiraraki pusat pelayanan Kota Pusat Pengembangan II, khususnya pada kawasan perkotaan Tanjung. Kota Pusat pengembangan II direncanakan memiliki skala pelayanan lebih dari satu kecamatan. Jenis fasilitas dan prasarana yang dilokasikan di kawasan perkotaan ini dirancang untuk memiliki pelayanan lebih dari satu kecamatan.

Sedangkan untuk arahan RTRW Kabupaten Brebes untuk pengembangan Desa Pusat Pertumbuhan (DPP), yang direncanakan untuk mengakomodir potensi perkembangan desa yang terkait dengan pengembangan kawasan minapolitan yaitu terdapat di Desa Kertobesuki (Kecamatan Wanasari), Desa Dumeling (Kecamatan Wanasari), dan Desa Kaliwlingi (Kecamatan Brebes). Arahan pengembangan pusat DPP tersebut diarahkan dengan fungsi pengembangan utama sebagai Kawasan Tambak dan Kawasan Sentra Industri Hasil Laut.

b) Kebijakan, strategi dan arahan pengembangan pola ruang

Arahan pengembangan pola ruang (kawasan budidaya perikanan) yang terdapat di wilayah pengembangan minapolitan (Kecamatan Losari, Tanjung, Bulakamba, Wanasari dan Brebes) adalah:

Kawasan perikanan di Kabupaten Brebes mencakup perikanan darat, laut dan tambak, dengan orientasi pengembangan pada pemanfaatan potensi.

Rencana pengembangan kawasan tambak dengan konservasi dan penataan kawasan tambak agar terjaga kualitas dan kuantitas produksi di Kec. Losari, Tanjung, Bulakamba, Wanasari dan Brebes.

Rencana pengembangan kawasan laut dengan optimalisasi wilayah 0-4 mil laut, pengembangan dermaga ikan, TPI dan pasar ikan serta terciptanya pelabuhan laut yang lebih representatif.

Analisis Regional. Analisis ini dilakukan untuk memahami kedudukan dan keterkaitan kawasan dalam sistem regional yang lebih luas dalam aspek sosial, ekonomi, lingkungan dan budaya. Kedudukan dan keterkaitan kawasan pengembangan minapolitan Kabupaten Brebes dapat digambarkan dari konstelasi regional kawasan minapolitan dengan wilayah yang terkait. Konstelasi regional yang berpengaruh dalam kegiatan Pemetaan Kawasan Budidaya dan Program Minapolitan adalah:

Konstelasi Kabupaten Brebes terhadap Provinsi Jawa Tengah. Kedudukan Kabupaten Brebes dalam Provinsi Jawa Tengah dapat dilihat dari arahan yang termuat dalam RTRW Provinsi Jawa Tengah. Secara struktur ruang, Kabupaten Brebes diarahkan pengembangannya sebagai Pusat Kegiatan Lokal (PKL) dengan Orde P3. Sedangkan dalam Sub Wilayah Pengembangan (SWP) Kabupaten Brebes termasuk ke dalam SWP IV yang meliputi Tegal-Slawi-Brebes-Pemalang dengan fungsi pengembangan sebagai Pusat Pelayanan Lokal, Provinsi dan Nasional. Potensi unggulan berupa industri besar, menengah dan kecil yang menghasilkan berbagai jenis produk pertanian, perkebunan, kayu, peternakan, perikanan dan kelautan, pertambangan, perdagangan dan jasa. segi transportasi, termasuk simpul transportasi provinsi dan nasional, simpul pariwisata dan pendidikan tinggi.

Kedudukan/keterkaitan Kabupaten Brebes juga dapat dilihat dari potensi pengembangan perikanan. Berdasarkan potensi perikanannya, Kabupaten Brebes termasuk kawasan budidaya perikanan Bagian Utara di Jawa Tengah. Adapun kawasan perikanan budidaya Bagian Utara di Jawa Tengah meliputi : Kabupaten Brebes, Kabupaten Tegal, Kota Tegal, Kabupaten Pemalang, Kabupaten Pekalongan, Kota Pekalongan, Kabupaten Batang, Kabupaten Kendal, Kota Semarang, Kabupaten Demak, Kabupaten Jepara, Kabupaten Kudus, Kabupaten Pati, dan Kabupaten Rembang.

Konstelasi Wilayah Pengembangan Kawasan Minapolitan Terhadap Kabupaten Brebes. Wilayah pengembangan kawasan minapolitan melalui kegiatan Pemetaan Kawasan Budidaya dan Program Minapolitan Kabupaten Brebes meliputi 5 (lima) wilayah kecamatan, yaitu Kecamatan Losari, Tanjung, Bulakamba, Wanasari dan Brebes yang mencakup 14 (empat belas) desa/kelurahan. Sesuai 
dengan konsep pengembangan kawasan minapolitan, maka kawasan minapolitan ini akan dikembangkan sebagai kawasan yang pusat pengembangan potensi perikanan yang saling mendukung satu sama lain secara fungsional dalam mempercepat pertumbuhan ekonomi daerah dan meningkatkan kesejahteraan rakyat.

Sedangkan kedudukan dan keterkaitan kawasan minapolitan dalam sistem regional yang lebih luas dalam aspek sosial dan budaya, ekonomi, dan lingkungan terhadap Kabupaten Brebes adalah:

Kondisi sosial dan budaya di kawasan minapolitan termasuk kedalam masyarakat pesisir. Wilayah pesisir yang terdapat di wilayah pengembangan kawasan minapolitan meliputi 18 desa pesisir (desa yang mempunyai garis pantai) dengan perincian: Kecamatan Brebes (5 desa pesisir), Kecamatan Wanasari (3 desa), Kecamatan Bulakamba (4 desa), Kecamatan Tanjung (2 desa) dan Kecamatan Losari (4 desa). Jumlah masyarakat yang tinggal di desa pesisir 123.150 jiwa $(7,73$ persen dari total populasi jumlah penduduk Kabupaten Brebes), dengan jumlah penduduk miskin sebanyak 44,249 jiwa $(8,850 \mathrm{KK})$ atau 36 persen dari jumlah masyarakat desa pesisir (Renstra Kelautan dan Perikanan, 2008-2012). Tingkat pendidikan masyarakat pesisir pada umumnya masih rendah (SD) dan hanya sebagian kecil saja yang berpendidikan lebih tinggi khususnya untuk anak-anak dari nelayan juragan dan pemilik tambak.

Kondisi ekonomi masyarakat di kawasan minapolitan dapat dilihat dari tingkat pendapatan masyarakat. Tingkat pendapatan masyarakat pesisir sebagian besar dengan tingkat pendatapan rata-rata masih rendah. Hal itu dikarenakan pada umumnya sebagai buruh nelayan dan buruh tambak.

Kondisi lingkungan pesisir yang menjadi kawasan minapolitan telah mengalami degradasi lingkungan yaitu terjadinya kerusakan mangrove yang berakibat pada terganggunya sumberdaya perikanan lainnya.

\section{Metode Penelitian}

\section{Teknik Pengumpulan Data}

Pengumpulan data dilakukan dalam dua cara, yaitu survei instansional dan pengamatan lapangan. Survei instansional dilakukan untuk memperoleh data-data sekunder, baik data-data numerik maupun data-data (dokumen) kebijakan dan peraturan-peraturan yang terkait.

Sedangkan Pengamatan lapangan dilakukan terutama untuk pengecekan ulang (crosscheck) data sekunder dengan fakta-fakta yang terjadi. Kegiatan terutama difokuskan untuk mengetahui komoditas wilayah yang mempunyai potensi untuk dikembangkan.

\section{Alat Analisis}

Alat yang digunakan adalah analisis deskriptif pembiayaan daerah, Location Quotient, NPV, IRR, B/C Ratio.

\section{Hasil dan Pembahasan}

Rencana hirarki kawasan perkotaan di kabupaten Brebes dapat ditentukan antara lain:

Kota pusat pengembangan Utama adalah kawasan perkotaan Brebes, kawasan perkotaan Ketanggungan, kawasan perkotaan Bumiayu. Kota Pusat pengembangan utama direncanakan memiliki skala pelayanan regional. Jenis fasilitas dan prasarana yang dilokasikan di kawasan perkotaan ini dirancang untuk memiliki pelayanan regional.

Kota pusat pengembangan II, yang meliputi kawasan perkotaan Tanjung, kawasan perkotaan Jatibarang. Kota Pusat pengembangan II direncanakan memiliki skala pelayanan lebih dari satu kecamatan. Jenis fasilitas dan prasarana yang dilokasikan di kawasan perkotaan ini dirancang untuk memiliki pelayanan lebih dari satu kecamatan.

Kota pusat pengembangan III meliputi kawasan perkotaan Bulakamba, Paguyangan, Sirampog, Banjarharjo, Tonjong, Wanasari, Bantarkawung, Loasari, Larangan, Kersana, Songgom dan Salem. Kota Pusat pengembangan III direncanakan memiliki skala pelayanan kecamatan. Jenis fasilitas dan prasarana yang dilokasikan di kawasan perkotaan ini dirancang untuk memiliki pelayanan kecamatan.

Desa Pusat Pertumbuhan (DPP), kawasan ini direncanakan untuk mengakomodir potensi perkembangan desa. Pengembangan DPP meliputi desa-desa yang direncanakan sebagai pusat dan desa-desa yang direncanakan sebagai 
kawasan mendapatkan pengaruh.

\section{Kawasan Perikanan}

Kawasan perikanan di Kabupaten Brebes mencakup perikanan darat, laut dan tambak, dengan orientasi pengembangan pada pemanfaatan potensi. Rencana yang akan dilaksanakan adalah:

a) Kawasan darat yang berbentuk kolam/ empang, kali dan waduk:

- Pusat pengembangan perikanan kolam di

Kec. Salem dan Bantarkawung
- Pusat pengembangan perikanan waduk di Malahayu dan Penjalin

b) Kawasan tambak dengan konservasi dan penataan kawasan tambak agar terjaga kualitas dan kuantitas produksi di Kecamatan Losari, Tanjung, Bulakamba, Wanasari, dan Brebes.

c) Kawasan laut dengan optimalisasi wilayah 0-4 mil laut, pengembangan dermaga ikan, TPI dan pasar ikan serta terciptanya pelabuhan laut yang lebih representatif.

Tabel 1. Desa Pusat Pertumbuhan Kabupaten Brebes

\begin{tabular}{|c|c|c|c|c|}
\hline KTP2D & Desa Pusat Pertumbuhan & Wilayah Pengaruh & Kecamatan & Fungsi Pengembangan Utama \\
\hline I & Bentar & $\begin{array}{l}\text { Tembograja } \\
\text { Pabuaran } \\
\text { Bentarsari } \\
\text { Ciputih } \\
\text { Ganggawang } \\
\text { Gandowang } \\
\text { Pasirpanjang }\end{array}$ & $\begin{array}{l}\text { Salem } \\
\text { Salem } \\
\text { Salem } \\
\text { Salem } \\
\text { Salem } \\
\text { Salem } \\
\text { Salem }\end{array}$ & $\begin{array}{l}\text { - Pertanian tanaman pangan lahan } \\
\text { kering } \\
\text { - Perdagangan } \\
\text { - Perhubungan dengan Salem } \\
\text { - Industri kecil }\end{array}$ \\
\hline II & Kalilangkap & $\begin{array}{l}\text { Kalinusu } \\
\text { Cinanas } \\
\text { Telaga } \\
\text { Cibentang } \\
\text { Banjarsari }\end{array}$ & $\begin{array}{l}\text { Bumiayu } \\
\text { Bantarkawung } \\
\text { Bantarkawung } \\
\text { Bantarkawung } \\
\text { Bantarkwung }\end{array}$ & $\begin{array}{l}\text { - Pertanian tanaman pangan lahan } \\
\text { kering } \\
\text { - Perdagangan } \\
\text { - Perhubungan dengan Bumiayu }\end{array}$ \\
\hline III & Dawuhan & $\begin{array}{l}\text { Sridadi } \\
\text { Kaligiri } \\
\text { Wanareja } \\
\text { Cipetung } \\
\text { Pandansari } \\
\text { Igirklanceng } \\
\text { Batursari }\end{array}$ & $\begin{array}{l}\text { Sirampog } \\
\text { Sirampog } \\
\text { Sirampog } \\
\text { Paguyangan } \\
\text { Paguyangan } \\
\text { Sirampog } \\
\text { Sirampog }\end{array}$ & $\begin{array}{l}\text { - Hutan negara } \\
\text { - Pertanian tahunan lahan kering } \\
\text { - Perkebunan } \\
\text { - Hutan lindung }\end{array}$ \\
\hline IV & Sindangwangi & $\begin{array}{l}\text { Kadumanis } \\
\text { Jemasih } \\
\text { Kebandungan } \\
\text { Pengarasan }\end{array}$ & $\begin{array}{l}\text { Salem } \\
\text { Ketanggunngan } \\
\text { Bantarkawung } \\
\text { Bantarkawung }\end{array}$ & $\begin{array}{l}\text { - Hutan Negara } \\
\text { - Pertanian Lahan Kering }\end{array}$ \\
\hline $\mathrm{V}$ & Pamulihan & $\begin{array}{l}\text { Kamal } \\
\text { Wlahar }\end{array}$ & $\begin{array}{l}\text { Larangan } \\
\text { Larangan }\end{array}$ & $\begin{array}{l}\text { - Hutan Negara } \\
\text { - Pertanian pangan lahan kering } \\
\text { - Pertanian tahunan lahan kering }\end{array}$ \\
\hline VI & Cikeusal Kidul & $\begin{array}{l}\text { Sindangjaya } \\
\text { Cikeusal Lor } \\
\text { Ciseureuh } \\
\text { Pamedaran } \\
\text { Sindanngjaya }\end{array}$ & $\begin{array}{l}\text { Ketanggungan } \\
\text { Ketanggungan } \\
\text { Ketanggungan } \\
\text { Ketanggungan } \\
\text { Ketanggungan }\end{array}$ & $\begin{array}{l}\text { - Pertambangan } \\
\text { - Pertanian lahan basah } \\
\text { - Hutan Negara } \\
\text { - Pertanian tahunan lahan kering }\end{array}$ \\
\hline VII & Bandungsari & $\begin{array}{l}\text { Penanggapan } \\
\text { Cipajang } \\
\text { Kertasari } \\
\text { Blandongan } \\
\text { Sindangheula }\end{array}$ & $\begin{array}{l}\text { Banjarharjo } \\
\text { Banjarharjo } \\
\text { Banjarharjo } \\
\text { Banjarharjo } \\
\text { Banjarharjo }\end{array}$ & $\begin{array}{l}\text { - Hutan negara } \\
\text { - Pertanian lahan kering } \\
\text { - Pertanian lahan basah } \\
\text { - Perhubungan dengan kabupaten } \\
\text { Kuningan }\end{array}$ \\
\hline VIII & Cikakak & $\begin{array}{l}\text { Cibendung } \\
\text { Karangmojo } \\
\text { Dukuhjenuk } \\
\text { Sukareja } \\
\text { Pende } \\
\text { Kubangrejo } \\
\text { Tiwulandu }\end{array}$ & $\begin{array}{l}\text { Banjarharjo } \\
\text { Banjarharjo } \\
\text { Banjarharjo } \\
\text { Banjarharjo } \\
\text { Banjarharjo } \\
\text { Banjarharjo } \\
\text { Banjarharjo }\end{array}$ & $\begin{array}{l}\text { - Pertanian lahan kering } \\
\text { - Pertanian lahan basah } \\
\text { - Perkebunan } \\
\text { - Jalur Alternatif } \\
\text { - Perdagangan }\end{array}$ \\
\hline IX & Bojongsari & $\begin{array}{l}\text { Randegan } \\
\text { Karangsambung } \\
\text { Karangjunti }\end{array}$ & $\begin{array}{l}\text { Losari } \\
\text { Losari } \\
\text { Losari }\end{array}$ & $\begin{array}{l}\text { - Pertanian lahan kering } \\
\text { - Pertanian lahan basah }\end{array}$ \\
\hline
\end{tabular}




\begin{tabular}{|c|c|c|c|c|}
\hline KTP2D & Desa Pusat Pertumbuhan & Wilayah Pengaruh & Kecamatan & Fungsi Pengembangan Utama \\
\hline \multirow{14}{*}{$\mathrm{X}$} & \multirow{12}{*}{ Sitanggal } & Jatisawit & Losari & \multirow{6}{*}{$\begin{array}{l}\text { - Perkebunan } \\
\text { - Jalur Alternatif }\end{array}$} \\
\hline & & Babakan & Losari & \\
\hline & & Dukuhsalam & Losari & \\
\hline & & Kalibuntu & Losari & \\
\hline & & Rungkang & Losari & \\
\hline & & Negla & Losari & \\
\hline & & Siandong & Larangan & - Pertanian Lahan basah \\
\hline & & Tegalgandu & Wanasari & - Pertanian lahan kering \\
\hline & & Siwungkuk & Wanasari & - Perhubungan \\
\hline & & Slatri & Larangan & - Perdagangan \\
\hline & & Rengaspenndawa & Larangan & \\
\hline & & Tegalglagah & Bulakamba & \\
\hline & \multirow{6}{*}{ Banjaratma } & Jagolempeni & Wanasari & \\
\hline & & Jubanng & Bulakamba & \multirow{5}{*}{$\begin{array}{l}\text { - Pertanian Lahan basah } \\
\text { - Pertanian lahan kering } \\
\text { - Perhubungan }\end{array}$} \\
\hline \multirow[t]{7}{*}{ XI } & & Siwuluh & Bulakamba & \\
\hline & & Petunjungan & Bulakamba & \\
\hline & & Tanjungsari & Wanasari & \\
\hline & & Sigentong & Wanasari & \\
\hline & & Dukuhringin & Wanasari & \\
\hline & & Glonggong & Wanasari & \\
\hline & & Sisalam & Wanasari & \\
\hline \multirow[t]{3}{*}{ XII } & Sawojajar & Kertobesuki & Wanasari & - Pertanian Lahan basah \\
\hline & & Dumeling & Wanasari & - Pertanian lahan kering \\
\hline & & Kaliwlingi & Brebes & $\begin{array}{l}\text { - Tambak } \\
\text { - Sentra industri hasil laut }\end{array}$ \\
\hline
\end{tabular}

Sumber: RTRW Kabupaten Brebes

\section{Komoditi Perikanan}

Produksi Perikanan Air Payau/Budidaya Tambak. Produksi perikanan dari hasil budidaya tambak ini merupakan potensi bagi pengembangan kawasan minapolitan. Kontinuitas produksi sangat diharapkan untuk memasok kebutuhan ikan baik untuk konsumsi maupun untuk industri minabisnis. Perikanan budidaya tambak yang dikembangkan di kawasan minapolitan antara lain udang, bandeng, rumput laut, blanak, mujahir, kakap, kepiting. Produksi tertinggi adalah bandeng (17.849.962 kg) dan rumput laut $(4.830 .313 \mathrm{~kg})$. Lebih jelasnya, dapat dilihat pada Tabel 2.

Produksi Perikanan Air Tawar/Kolam. Produksi yang terbesar dari hasil kolam lele
Perikanan budidaya air tawar/kolam yang berkembang di kawasan minapolitan adalah kolam lele dan mujahir.

Tabel 3. Produksi Perikanan Perairan Kolam (dalam kg)

\begin{tabular}{clrc}
\hline No & Kecamatan & Lele & Mujahir \\
\hline 1 & Losari & 24.654 & 0 \\
2 & Tanjung & 0 & 0 \\
3 & Bulakamba & 117.330 & 139 \\
4 & Wanasari & 10.646 & 0 \\
5 & Brebes & 126.420 & 0 \\
& Jumlah & 279.050 & 139 \\
\hline Sumber: & Dinas Kelautan dan Perikanan Kabupaten Brebes \\
2010 & &
\end{tabular}

Tabel 2. Produksi Perikanan Budidaya Tambak Kawasan Minapolitan (dalam kg)

\begin{tabular}{|c|c|c|c|c|c|c|c|}
\hline No & Jenis Ikan & Losari & Tanjung & Bulakamba & Wanasari & Brebes & Jumlah \\
\hline 1 & Rumput Laut & 1.138 & 0 & 526.270 & 0 & 4.302 .905 & 4.830 .313 \\
\hline 2 & Bandeng & 1.590 .811 & 949.287 & 7.021 .035 & 1.404 .981 & 6.883 .849 & 17.849 .963 \\
\hline 3 & Udang Windu & 154.109 & 388.136 & 119.296 & 12.335 & 679.758 & 1.353 .634 \\
\hline 4 & Udang Vaname & 0 & 0 & 0 & 0 & 72.448 & 72.448 \\
\hline 5 & Udang Putih & 0 & 0 & 36.949 & 37.796 & 148.828 & 223.573 \\
\hline 6 & Udang Lain & 0 & 0 & 1.791 .673 & 250.442 & 618.685 & 2.660 .800 \\
\hline 7 & Blanak & 0 & 0 & 40.679 & 0 & 55.087 & 95.766 \\
\hline 8 & Kakap & 0 & 0 & 8.214 & 2.471 & 20.868 & 31.553 \\
\hline 9 & Kepiting & 0 & 0 & 1.085 & 0 & 104.105 & 105.190 \\
\hline 10 & Mujahir & 0 & 0 & 400.169 & 43.679 & 797.514 & 1.241 .362 \\
\hline 11 & Lainnya & 164.700 & 0 & 0 & 0 & 160.246 & 324.946 \\
\hline
\end{tabular}

Sumber: Dinas Kelautan dan Perikanan Kabupaten Brebes, 2010 
mencapai $279.050 \mathrm{~kg}$, sedangkan mujahir dibudidayakan di Bulakamba, Wanasari dan Brebes.

\section{Perikanan Tangkap}

Selain perikanan budidaya yang ada di kawasan minapolitan, potensi perikanan lain yang ada dan memberikan pengaruh pada industri pengolahan hasil perikanan di Kabupaen Brebes tadalah perikanan tangkap. Perikanan tangkap yang ada di kawasan minapolitan terdiri dari tangkapan laut dan sungai.

\section{Produksi Perikanan Laut}

Produksi perikanan laut merupakan perikanan hasil tangkapan nelayan. Jenis ikan yang ditangkap antara lain kembung, tembang/jui, bilis, sriding, teri, lemuru, pari, kuniran, bloso, pirik, cumi-cumi, tongkol, rajungan. Pada umumnya, hasil tangkapan ikan nelayan akan masuk ke TPI dan kemudian akan dilelang. Produksi ikan yang masuk ke TPI, dapat dilihat pada Tabel 4 dalam Lampiran.

\section{Produksi Perikanan Perairan Umum (sungai)}

Perikanan perairan umum didapatkan dari hasil tangkapan disejumlah sungai yang ada di kawasan perencanaan. Tidak seperti perikanan budidaya, kecenderungan kontinuitas produksi ikan tidak dapat diandalkan, karena tergantung ketersediaan ikan di perairan sungai. Jenis ikan yang dihasilkan dari tangkapan sungai antara lain mujaher, udang, blanak, dan rucah, dapat dilihat pada Tabel 5 dalam Lampiran.

\section{Analisis Pembiayaan Pembangunan}

Analisis ini untuk mengidentifikasi sumbersumber pembiayaan pembangunan dan besarnya biaya pembangunan baik dari PAD (Pendapatan Asli Daerah), DAU (Dana Alokasi Umum) dan DAK (Dana Alokasi Khusus), dan permodalan (investasi/ dana bantuan dan pinjaman). Berikut merupakan uraian kajian analisis pembiayaan pembangunan yang terkait dengan pengembangan kawasan minapolitan.

\section{PAD (Pendapatan Asli Daerah)}

Berdasarkan data statistik Tahun 2008, dapat diketahui Pendapatan Asli daerah (PAD) Kabupaten Brebes secara makro senilai:

Rp71.896.767.269,-. PAD tersebut dihasilkan dari beberapa sumber pendapatan yaitu: Pendapatan Pajak Daerah senilai Rp14.630.524.271; Pendapatan Retribusi Daerah senilai:

Rp26.719.501.739,-; Pendapatan Hasil Pengelolaan Kekayaan Daerah yang dipisahkan senilai Rp2.497.471.575,- ; dan Lain-lain Pendapatan Asli Daerah yang sah senilai:

Rp28.049.269.684,--.

Secara sektoral perikanan, dalam Tahun Anggaran 2009 Dinas kelautan dan Perikanan ditarget untuk Pendapatan Asli Daerah (PAD) sebesar Rp101.100.000,- dengan rincian pada Tabel 6.

Berdasarkan Tabel 6 dapat digambarkan bahwa pada Tahun 2009, realisasi PAD Dinas kelautan dan perikanan Kabupaten Brebes mengalami kenaikan sebesar 0,008 dari nilai yang ditargetkan. Hal ini disebabkan karena adanya kenaikan penerimaan retribusi penjualan produksi usaha daerah, di antaranya Tambak Dinas, BBI dan Bisnis Perikanan yang melebihi target.

DAU (Dana Alokasi Umum) dan DAK (Dana Alokasi Khusus)

Nilai Dana Alokasi Umum (DAU) Kabupaten Brebes secara umum Tahun 2008 adalah senilai Rp716.426.000.000,-. Sedangkan untuk Dana Alokasi Khusus (DAK) yaitu sebesar Rp10.334.000.000,-. Secara sektoral pembangunan perikanan, dalam Tahun 2009 Dinas Kelautan dan Perikanan Kabupaten Brebes mengelola anggaran pembangunan sebesar:

Rp2.935.000.000,- dari dana APBD Kabupaten

Tabel 6. Target dan Pencapaian Pendapatan Asli Daerah Dinas Kelautan dan Perikanan Kabupaten Brebes Tahun 2009

\begin{tabular}{|c|c|c|c|c|}
\hline No & Uraian & Target (Rp) & Pencapaian (Rp) & $(\%)$ \\
\hline 1 & Penerimaan Retribusi Pelelangan Ikan & $34.000 .000,00$ & $34.976 .562,00$ & 102,87 \\
\hline 2 & Pengelolaan Tambak Dinas & $30.000 .000,00$ & $30.000 .000,00$ & 100,00 \\
\hline 3 & Pengelolaan BBI & $4.000 .000,00$ & $4.000 .000,00$ & 100,00 \\
\hline 4 & Pengelolaan Aquabisnis & $31.000 .000,00$ & $31.020 .000,00$ & 100,06 \\
\hline 5 & Penyertaan Modal Perikanan & $2.100 .000,00$ & $2.100 .000,00$ & 100,00 \\
\hline & Jumlah & $101.100 .000,00$ & $102.096 .562,00$ & 102,93 \\
\hline
\end{tabular}

Sumber: Laporan Tahunan Dinas Perikanan dan Kelautan Kab. Brebes, 2008-2009 dan Hasil olahan 2010 
Brebes (DAU) dan Dana Aloksi Khusus (DAK).

Berdasarkan Tabel 7 dalam Lampiran, dapat diketahui realisasi penggunaan anggaran pembangunan tahun 2009 senilai:

Rp2.659.215.960,00 atau sebesar 91,00 persen. Jumlah tersebut lebih sedikit jika dibandingkan dengan nilai rupiah yang dianggarkan. Selisih antara anggaran dengan realisasi penggunaan anggaran adalah sebesar Rp275.784.040,00,-.

\section{Permodalan}

Permodalan di sini dapat digambarkan oleh investasi, dana bantuan dan pinjaman dalam pengembangan perikanan dan kelautan dan kawasan minapolitan secara makro. Permodalan merupakan salah satu keluhan pembudidaya yang banyak dijumpai oleh pembudidaya ikan. Keterbatasan modal usaha tersebut disebabkan karena semakin tingginya biaya produksi yang harus dikeluarkan. Sebagai besar pembudidaya memilih melaksanakan usaha budidaya dengan modal seadanya, sehingga berdampak usaha budidaya yang dilakukan tidak sesuai dengan tenis anjuran. Hal ini berdampak pada hasil produksi yang kurang optimal.

Sumber permodalan yang ada seperti perbankan belum dapat dimanfaatkan oleh pembudidaya, hal ini dikarenakan kurangnya sosialisasi dari pihak perbankan. Selain dari pihak perbankan, sumber permodalan lain seperti investor belum banyak berminat, akan tetapi rintisan kearah tersebut mulai dilakukan oleh beberapa pembudidaya.

Arahan pengembangan kawasan minapolitan melalui permodalan akan ditekankan pada upaya pendekatan kepada sumber-sumber permodalan agar dapat mengalokasikan bantuan/pinjaman modal usaha bagi pembudidaya/POKDAKAN dengan sistem yang lebih mudah dan meringankan pembudidaya. Selain itu akan dilakukan penjajakan terhadap peluang-peluang investasi budidaya kepada calon investor baik lokal mapun nasional. Bantuan permodalan pengembangan kawasan minapolitan dapat di alokasikan dari sumber APBN, APBD Provinsi Jawa Tengah dan APBD Kabupaten Brebes.

\section{Tahap-tahapan industrialisasi}

Indikator dalam perkembangan pembangunan dapat dilihat sejauh mana industrialisasi di Kabupaten Brebes. Tahap-tahap industrialisasi ini dikemukakan oleh UNIDO atau Bank Dunia dirasa jauh berhasil karena memperhatikan proses perkembangan industri.

Sektor pertanian menjadi industri penuh karena memberikan kontribusi yang paling besar bagi pembentukan PDRB (52,81\%), dimana sektor pertanian bisa menjadi ujung tombak bagi pertumbuhan ekonomi Kabupaten Brebes dan sebagai pemicu bagi pertumbuhan sektor lainnya di Kabupaten Brebes. Disusul dari sektor perdagangan, hotel dan restoran yang menjadi turunan dari efek berkembangnya sektor pertanian $(20,3 \%)$.

Tabel 8. Tahapan Industrialisasi

\begin{tabular}{clcc}
\hline & & \multicolumn{2}{c}{$\begin{array}{c}\text { Sumbang VA \% } \\
\text { terhadap }\end{array}$} \\
No & \multicolumn{1}{c}{ Tahap } & PDRB & $\begin{array}{c}\text { Sektor } \\
\text { Komoditi }\end{array}$ \\
& & $<10$ & $<20$ \\
\hline 1 & Non Industrialisasi & & \\
& Menuju proses & $10-20$ & $20-40$ \\
2 & industrialisasi & $20-30$ & $40-60$ \\
3 & Semi industrialisasi & $>30$ & $>60$ \\
4 & Industri penuh & & \\
\hline
\end{tabular}

Sektor industri pengolahan menjadi infant industry dimana dalam proses transisi dari pengolahan bahan baku menjadi barang jadi. Sedangkan lima sektor lainnya dalam tahapan non industri karena secara tidak langsung tidak berpengaruh langsung terhadap berkembangnya sektor pertanian.

Tabel 9. Tahapan Proses Industrialisasi Di Kabupaten Brebes Tahun 2009

\begin{tabular}{|c|c|c|c|}
\hline No & Sektor & $\begin{array}{c}\text { Kontribusi } \\
(\%)\end{array}$ & Tahapan \\
\hline \multirow[t]{9}{*}{1} & Jasa-jasa & 4,74 & Non \\
\hline & $\begin{array}{l}\text { Keuangan, } \\
\text { persewaan \& jasa }\end{array}$ & & Industrialisasi \\
\hline & perusahaan & 2,84 & \\
\hline & Bangunan dan & & \\
\hline & konstruksi & 2,14 & \\
\hline & Pertambangan & & \\
\hline & dan penggalian & 1,31 & \\
\hline & Listrik, gas dan & & \\
\hline & air bersih & 0,88 & \\
\hline 2 & $\begin{array}{l}\text { Industri } \\
\text { pengolahan }\end{array}$ & 12,08 & $\begin{array}{l}\text { Menuju proses } \\
\text { industrialisasi }\end{array}$ \\
\hline 3 & $\begin{array}{l}\text { Perdagangan, } \\
\text { hotel, dan } \\
\text { restoran }\end{array}$ & 20,3 & $\begin{array}{l}\text { Semi } \\
\text { industrialisasi }\end{array}$ \\
\hline 4 & Pertanian & 52,81 & Industri penuh \\
\hline
\end{tabular}


Sumber : Pendapatan Regional Kabupaten Brebes yang telah diolah, 2011

\section{Analisis Sektor Basis (LQ)}

Terkait dengan aliran pergerakan barang dan jasa intra serta inter Kabupaten, pada bagian ini terlebih dahulu akan dilakukan identifikasi sektor strategis yang diarahkan untuk mengetahui sektor-sektor yang memiliki keunggulan untuk dikembangkan di wilayah Kabupaten Brebes, dilihat dari potensi, penciptaan pendapatan dan lapangan kerja, maupun interaksinya dengan sektor-sektor lain di dalam dan luar daerah sehingga dapat diketahui sektor yang mampu mencukupi kebutuhan masyarakat di dalam wilayah Kabupaten Brebes sendiri dan berpotensi untuk bergerak ke luar wilayah.

Untuk mengetahui spesifikasi relatif sektor atau kegiatan ekonomi tertentu di suatu wilayah perencanaan, maka dapat digunakan Metode Location Quatien (LQ). Variabel pengukuran yang digunakan disini untuk melihat sektor basis wilayah, dimana untuk melihat komoditas yang berpotensi mendukung pengembangan wilayah adalah variabel Produk Domestik Regional Bruto (PDRB) wilayah perencanaan Kabupaten Brebes dan PDRB daerah acuan, yang dalam hal ini adalah Provinsi Jawa Tengah. Kriteria umum yang digunakan dalam penentuan sektor basis dengan metode LQ:

Jika LQ $\geq 1$ disebut sektor basis, yaitu sektor yang spesialisasinya lebih besar daripada tingkat wilayah acuannya.

Jika LQ $<1$ disebut sektor nonbasis, yaitu sektor yang tingkat spesialisasinya lebih kecil daripada tingkat wilayah acuan.

Analisis perhitungan LQ di Kabupaten Brebes dihitung berdasarkan PDRB Kabupaten Brebes dibandingkan dengan PDRB Provinsi Jawa Tengah. Berdasarkan hasil perhitungan tersebut dapat diketahui bahwa sektor ekonomi di Kabupaten Brebes yang menjadi sektor basis salah satunya sektor perikanan di lima (5) Kecamatan yaitu Losari, Bulakamba,Wanasari, Tanjung dan Brebes, dapat dilihat Tabel 10 dalam Lampiran.

\section{Analisis Biaya Budidaya Rumput Laut}

Pembudidayaan rumput laut di Kabupaten Brebes dihitung berdasarkan pada dua kondisi, yaitu kondisi optimal pada saat cuaca cerah (panen raya) dan kondisi pesimis (kondisi iklim yang tidak mengguntungkan).

Pada saat musim panen (optimum) rumput laut membutuhkan total investasi:

Rp45.871.250.000 (dapat dilihat pada Tabel 11 dalam Lampiran).

Investasi yang dibutuhkan pada saat (kondisi pesimis) panen rumput laut di Kabupaten Brebes sebesar Rp17.776.000.000. (dapat dilihat pada Tabel 12 dalam Lampiran).

\section{Penerimaan Budidaya Rumput Laut}

Penerimaan hasil budidaya rumput laut basah di Kabupaten Brebes tahun 2011 sebesar Rp157.500.000.000 dan rumput laut kering sebelum diolah Rp. 315.000.000.000 (dapat dilihat pada Tabel 13 dan Tabel 14 dalam Lampiran).

\section{Analisis Investasi Rumput Laut}

Hasil perhitungan diketahui dengan kondisi pesimis, nilai investasi yang dibutuhkan untuk budidaya rumput laut sebesar:

Rp45.871.250.000, untuk kondisi pesimis budidaya rumput laut dibutuhkan investasi:

Rp17.776.000.000 dengan masa investasi 25 tahun maka din peroleh cash in flow:

Rp317.810.803.865 (kondisi pesimis) dan

Rp214.994.952.682 (kondisi pesimis). Dalam kondisi optimis NPV dengan degree of freedom $(\mathrm{df})=10 \%$ adalah Rp. 433.483.235.810, $\mathrm{df}=12 \%$ sebesar Rp439.257.549.031, df $=14 \%$ sebesar Rp438.857.374.827 (dapat dilihat pada Tabel 15 dalam Lampiran).

\section{Simpulan}

Pemerintah Daerah Kabupaten Brebes memiliki program Kawasan Minapolitan (Mina = Ikan Poli = Kota) dimana salah satunya adalah budidaya rumput laut di lima (5) Kecamatan Di Kabupaten Brebes, yaitu Kecamatan Brebes, Bulakamba,Tanjung, Wanasari dan Losari.

Dengan adanya upaya investasi rumput laut akan mendukung dari perkembangan Kawasan Minapolitan Di Kabupaten Brebes.

Hasil budidaya rumput lautmenunjukkan bahwa diketahui dengan kondisi optimis, nilai investasi yang dibutuhkan untuk budidaya rumput laut sebesar Rp45.871.250.000, untuk kondisi pesimis budidaya rumput laut dibutuhkan investasi Rp17.776.000.000 dengan 
masa investasi 25 tahun maka diperoleh cash in flow:

Rp317.810.803.865 (kondisi optimis) dan Rp214.994.952.682 (kondisi pesimis). Dalam kondisi optimis NPV dengan degree of freedom $(\mathrm{df})=10 \%$ adalah $\mathrm{Rp} 433.483 .235 .810, \mathrm{df}=12 \%$ sebesar Rp439.257.549.031, df $=14 \%$ sebesar Rp438.857.374.827. Artinya investasi rumput laut yang akan dilakukan di Kabupaten Brebes akan menguntungkan dan akan menjadi sumber Pendapatan Asli Daerah Kabupaten Brebes.

Rekomendasi. Dalam meningkatakan daya dukung kawasan Minapolitan melalui investasi rumput laut di Kabupaten Brebes dilakukan berbagai kegiatan usaha berikut:

a) Peningkatan penyuluhan ketrampilan atau pelatihan bagi petani nelayan, dalam rangka peningkatan kualitas sumberdaya manusia.

b) Pengembangan sarana penyuluhan, sedemikian hingga memungkinkan percepatan alih teknologi kepaada masyarakat.

c) Pengembangan paket teknologi berproduksi dan pasca panen.

d) Pembinaan dan pengembangan sarana produksi.

e) Pembinaan pasca panen dan pemasaran hasil usaha perikanan, melalui proses pengolahan hasil serta promosi dan distribusinya kepada konsumen.

f) Pengembangan sarana dan prasarana perikanan.

g) Pembinaan sumberdaya alam dan lingkungan hidup.

\section{Daftar Pustaka}

Widjaja, A.W. 2001. Pemerintahan Desa/ Marga Berdasarkan UU. No. 22 Tahun 1999 Tentang Pemerintah Daerah, Jakarta: PT. Raja Garafindo Persada.

Hakim, Saeful. Ernan Rustiadi, Dyah R. Panuju, dkk, 2002. Perencanaan dan Pengembangan Wilayah. Jakarta: Crepest Press dan Yayasan Obor Indonesia.

Halim, Abdul. 2001. Manajemen Keuangan Daerah. Yogyakarta: AMP YKPN.

Mardiyasmo. 2002. Otonomi dan Manajemen Keuangan Daerah. Yogyakarta: Penerbit Andi.

Perda Kabupaten Brebes No. 1 Tahun 2010 tentang Anggaran Pendapatan dan Belanja Daerah Kabupaten Brebes Tahun Anggaran 2010

Perda Kabupaten Brebes No. 15 Tahun 2001 tentang Evaluasi dan Revisi Rencana Tata Ruang Wilayah Kabupaten Brebes 2001-2010

Perda Kabupaten Brebes No. 3 Tahun 2008 tentang Urusan Pemerintahan yang menjadi Kewenangan Pemerintah Daerah Kabupaten Brebes

Perda Kabupaten Brebes No. 2 Tahun 2008 tentang rencana Pembangunan Jangka Menengah Daerah Kabupaten Brebes Tahun 20082012

PP RI No. 1 Tahun 2008 tentang Investasi Pemerintah

PP No. 58 Tahun 2005 tentang Pengelolaan Keuangan Daerah

UU No. 26 Tahun 2007 tentang Penataan Ruang

UU No. 32 Tahun 2004 tentang Pemerintah Daerah yang telah diubah beberapa kali terakhir dengan UU No. 12 Tahun 2008 tentang Perubahan Kedua atas UU No. 32 Tahun 2004 tentang Pemerintahan Daerah

UU No. 33 Tahun 2004 tentang Perimbangan Keuangan antar Pemerintah Pusat dan Pemerintah Daerah

\section{Lampiran}

Tabel 4. Produksi Ikan Per TPI Tahun 2009 (dalam kg)

\begin{tabular}{clccccccc}
\hline No & $\begin{array}{c}\text { Jenis } \\
\text { lkan }\end{array}$ & Kaligangsa & Kaliwlingi & Sawojajar & $\begin{array}{c}\text { Pulolampe } \\
\text { s }\end{array}$ & $\begin{array}{c}\text { Kluwut } \\
\text { Kraka } \\
\text { han }\end{array}$ & $\begin{array}{c}\text { Pengaradan } \\
\text { Kidul }\end{array}$ \\
\hline 1 & Kembung & 346 & 1.554 & 0 & 36 & 0 & 0 & 0 \\
2 & Kerang & 0 & 0 & 0 & 0 & 0 & 0 & 0 \\
3 & Rajungan & 0 & 0 & 0 & 0 & 0 & 0 \\
4 & Bawal & 0 & 315 & 0 & 0 & 0 & 0 & 0 \\
5 & Teri jawa & 0 & 0 & 44.537 & 4.478 & 0 & 0 & 0 \\
6 & Udang & 0 & 0 & 0 & 0 & 0 & 0 & 0 \\
& krosok & & & & & & & 0
\end{tabular}




\begin{tabular}{|c|c|c|c|c|c|c|c|c|c|}
\hline No & $\begin{array}{l}\text { Jenis } \\
\text { Ikan }\end{array}$ & Kaligangsa & Kaliwlingi & Sawojajar & $\begin{array}{c}\text { Pulolampe } \\
\text { s } \\
\end{array}$ & Kluwut & $\begin{array}{c}\text { Kraka } \\
\text { han }\end{array}$ & Pengaradan & $\begin{array}{c}\text { Prapag } \\
\text { Kidul }\end{array}$ \\
\hline 7 & $\begin{array}{l}\text { Tembang/ } \\
\text { jui }\end{array}$ & 0 & 0 & 0 & 13.526 & 0 & 0 & 0 & 0 \\
\hline 8 & Bilis & 0 & 0 & 0 & 35.296 & 0 & 0 & 0 & 0 \\
\hline 9 & Sriding & 0 & 0 & 0 & 60.736 & 0 & 0 & 0 & 0 \\
\hline 10 & lemuru & 0 & 0 & 0 & 3.918 & 0 & 0 & 0 & 0 \\
\hline 11 & Kuniran & 0 & 0 & 0 & 0 & 52.400 & 0 & 0 & 0 \\
\hline 12 & Petek & 0 & 0 & 0 & 0 & 132.150 & 0 & 0 & 0 \\
\hline 13 & Pari/Peh & 0 & 0 & 0 & 0 & 29.510 & 0 & 0 & 0 \\
\hline 14 & Bloso & 0 & 0 & 0 & 0 & 94.825 & 0 & 0 & 0 \\
\hline 15 & $\begin{array}{l}\text { Cumi- } \\
\text { cumi }\end{array}$ & 0 & 0 & 0 & 0 & 0 & 0 & 0 & 0 \\
\hline 16 & Pirik & 0 & 0 & 0 & 0 & 1.027 .877 & 0 & 0 & 0 \\
\hline 17 & Teri nasi & 0 & 0 & 0 & 0 & 0 & 55.828 & 41.904 & 0 \\
\hline 18 & Tongkol & 0 & 0 & 0 & 0 & 0 & 0 & 0 & 0 \\
\hline 19 & Lain-lain & 0 & 0 & 0 & 10.051 & 0 & 0 & 0 & 0 \\
\hline \multicolumn{2}{|c|}{ Jumlah } & 346 & 1.869 & 44.537 & 128.041 & 1.336 .762 & 55.828 & 41.904 & 25 \\
\hline
\end{tabular}

Sumber: Dinas Kelautan dan Perikanan Kabupaten Brebes, 2010

Tabel 5. Produksi Perikanan Perairan Umum (Sungai) Kawasan Minapolitan (dalam kg)

\begin{tabular}{clccc}
\hline No & \multicolumn{1}{c}{ Kecamatan (Sungai) } & Mujaher, Udang Lainnya & Rucah & Blanak \\
\hline 1 & Brebes (Kaligangsa) & 10.051 & 57.491 & 4.333 \\
2 & Wanasari (S. Sawojajar) & 97.167 & 35.323 & 97.321 \\
3 & Bulakamba (S. Kluwut, Pakijangan) & 7.620 & 5.021 & 10.282 \\
4 & Tanjung (S. Krakahan) & 12.384 & 30.971 & 13.994 \\
5 & Losari & 10.382 & 45.321 & 15.432 \\
& \multirow{2}{*}{ Jumlah } & 137.604 & 174.127 & 141.362 \\
\hline
\end{tabular}

Sumber: Dinas Kelautan dan Perikanan Kabupaten Brebes, 2010

Tabel 6. Target dan Pencapaian Pendapatan Asli Daerah Dinas Kelautan dan Perikanan Kabupaten Brebes Tahun 2009

\begin{tabular}{|c|c|c|c|c|}
\hline No & Uraian & Target (Rp) & Pencapaian (Rp) & $(\%)$ \\
\hline 1 & Penerimaan Retribusi Pelelangan Ikan & $34.000 .000,00$ & $34.976 .562,00$ & 102,87 \\
\hline 2 & Pengelolaan Tambak Dinas & $30.000 .000,00$ & $30.000 .000,00$ & 100,00 \\
\hline 3 & Pengelolaan BBI & $4.000 .000,00$ & $4.000 .000,00$ & 100,00 \\
\hline 4 & Pengelolaan Aquabisnis & $31.000 .000,00$ & $31.020 .000,00$ & 100,06 \\
\hline 5 & Penyertaan Modal Perikanan & $2.100 .000,00$ & $2.100 .000,00$ & 100,00 \\
\hline & Jumlah & $101.100 .000,00$ & $102.096 .562,00$ & 102,93 \\
\hline
\end{tabular}

Sumber: Laporan Tahunan Dinas Perikanan dan Kelautan Kab. Brebes, 2008-2009 dan Hasil olahan 2010

Tabel 7. Kegiatan Pembangunan dari Dana DAU dan DAK Kabupaten Brebes Tahun 2009

\begin{tabular}{|c|c|c|c|c|}
\hline No & Uraian & $\begin{array}{l}\text { Anggaran } \\
\text { Nilai (Rp) }\end{array}$ & $\begin{array}{l}\text { Realisasi } \\
\text { Nilai (Rp) }\end{array}$ & $(\%)$ \\
\hline 1 & Pembinaan kelompok ekonomi masyarakat pesisir & $35.000 .000,00$ & $27.967 .000,00$ & 79,91 \\
\hline 2 & Pengelolaan lingkungan berbasis pemberdayaan masyarakat & $150.000 .000,00$ & $141.385 .000,00$ & 94,26 \\
\hline 3 & $\begin{array}{l}\text { Kajian dan identifikasi teknis pengelolaan sumber daya kelautan dan } \\
\text { perikanan }\end{array}$ & $65.000 .000,00$ & $58.182 .500,00$ & 89,51 \\
\hline 4 & $\begin{array}{l}\text { Pendampingan PNPM-MKP (Program Nasioanl Pemberdayaan } \\
\text { Masyarakat-Mandiri Kelautan Perikanan) }\end{array}$ & $150.000 .000,00$ & $142.811 .000,00$ & 95,21 \\
\hline 5 & Pemberdayaan Kelompok Masyarakat Pengawas di wilayah Brebes & $30.000 .000,00$ & $29.330 .000,00$ & 97,77 \\
\hline 6 & Penanaman Mangrove di kawasan pesisir Kabupaten Brebes & $60.000 .000,00$ & $56.875 .000,00$ & 94,79 \\
\hline 7 & $\begin{array}{l}\text { Pengelolaan dan rehabilitasi terumbu karang, mangrove, padang } \\
\text { lamun, estuaria dan teluk }\end{array}$ & $100.000 .000,00$ & $99.291 .000,00$ & 99,29 \\
\hline 8 & Pengendalian kelestariaan sumberdaya ikan dan lingkungan & $60.000 .000,00$ & $60.000 .000,00$ & 100,00 \\
\hline 9 & Pengawasan dan pengendalian kelestarian & $50.000 .000,00$ & $40.994 .460,00$ & 81,99 \\
\hline 10 & Penyusunan Peraturan Daerah Bidang Kelautan dan Perikanan & $110.000 .000,00$ & $75.277 .000,00$ & 68,43 \\
\hline 11 & Penyuluhan Budaya Kelautan & $50.000 .000,00$ & $34.074 .000,00$ & 68,15 \\
\hline 12 & Pengembangan Bisnis perikanan dan kelautan & $130.000 .000,00$ & $124.530 .000,00$ & 65,79 \\
\hline 13 & Revitalisasi lahan tambak & $80.000 .000,00$ & $77.685 .000,00$ & 97,11 \\
\hline 14 & Pengembangan Bisnis perikanan dan kelautan & $80.000 .000,00$ & $67.030 .000,00$ & 83,79 \\
\hline 15 & Uji terap budidaya rumput laut sistem long line & $70.000 .000,00$ & $66.062 .000,00$ & 94,37 \\
\hline 16 & Uji terap budidaya ikan laut & $40.000 .000,00$ & $40.000 .000,00$ & 100,00 \\
\hline 17 & Uji terap budidaya polycultur udang vaname dan bandeng & $80.000 .000,00$ & $74.370 .000,00$ & 92,26 \\
\hline
\end{tabular}




\begin{tabular}{|c|c|c|c|c|}
\hline No & Uraian & $\begin{array}{c}\text { Anggaran } \\
\text { Nilai (Rp) } \\
\end{array}$ & $\begin{array}{l}\text { Realisasi } \\
\text { Nilai (Rp) }\end{array}$ & (\%) \\
\hline 18 & Pemberdayaan Kelompok pembudidaya ikan & $50.000 .000,00$ & $49.988 .000,00$ & 99,98 \\
\hline 19 & Peningkatan sumberdaya ikan penunjang pendapatan nelayan & $70.000 .000,00$ & $69.975 .000,00$ & 99,96 \\
\hline 20 & Pengadaan alat tangkap ramah lingkungan & $40.000 .000,00$ & $39.887 .000,00$ & 99,72 \\
\hline 21 & Pembuatan terumbu karang buatan sebagai rumpon & $100.000 .000,00$ & $99.154 .000,00$ & 99,15 \\
\hline 22 & Peningkatan kapasitas SDM nelayan & $30.000 .000,00$ & $23.375 .000,00$ & 77,92 \\
\hline 23 & Rintisan tempat pelelangan ikan di kawasan perairan umum & $30.000 .000,00$ & $20.164 .000,00$ & 67,21 \\
\hline 24 & Pelatihan peningkatan SDM perikanan dan kelautan & $25.000 .000,00$ & $24.993 .000,00$ & 99,97 \\
\hline 25 & Peningkatan sarana laboratorium kelautan dan perikanan & $20.000 .000,00$ & $19.440 .000,00$ & 97,20 \\
\hline 26 & Pengelolaan tambak dinas & $70.000 .000,00$ & $64.830 .000,00$ & 92,61 \\
\hline 27 & Promosi produk andalan perikanan dan kelautan & $60.000 .000,00$ & $58.397 .000,00$ & 97,33 \\
\hline 28 & Pengelolaan balai benih ikan (BBI) Mahalayu & $60.000 .000,00$ & $57.804 .000,00$ & 96,34 \\
\hline 29 & Rehabilitasi BBI lokal Mahalayu & $260.000 .000,00$ & $183.065 .000,00$ & 70,41 \\
\hline 30 & Pengadaan sarana pengolahan hasil perikanan & $100.000 .000,00$ & $98.672 .500,00$ & 98,67 \\
\hline 31 & Pelatihan dan penanganan pasca panen produk simping & $25.000 .000,00$ & $24.744 .000,00$ & 98,98 \\
\hline 32 & Rehabilitasi tambak dinas & $50.000 .000,00$ & $43.320 .000,00$ & 86,64 \\
\hline 33 & Pembinaan dan pelatihan bagi pengolah hasil perikanan & $75.000 .000,00$ & $73.704 .500,00$ & 98,27 \\
\hline 34 & Sosialisasi dan identifikasi pengolahan TPI & $70.000 .000,00$ & $64.954 .000,00$ & 92,79 \\
\hline 35 & Bantuan alat pengolah rumput laut & $20.000 .000,00$ & $19.365 .000,00$ & 96,83 \\
\hline 36 & Peningkatan kegiatan penjualan ikan di pasar & $40.000 .000,00$ & $34.500 .000,00$ & 86,25 \\
\hline 37 & Pengembangan perikanan di kawasan agropolitan & $90.000 .000,00$ & $87.800 .000,00$ & 97,56 \\
\hline 38 & Pembinaan revitalisasi tambak udang vaname & $80.000 .000,00$ & $67.520 .000,00$ & 84,40 \\
\hline 39 & Validasi data perikanan dan kelautan & $30.000 .000,00$ & 29.701.000,00 & 99,00 \\
\hline 40 & Penunjang pelaksanaan pengadaan barang dan jasa & $10.000 .000,00$ & $7.210 .000,00$ & 72,10 \\
\hline 41 & Pengembangan kawasan konservasi perairan (KKP) & $85.000 .000,00$ & $76.710 .000,00$ & 90,25 \\
\hline 42 & Penyusunan Database penagkapan ikan & $30.000 .000,00$ & $29.305 .000,00$ & 97,68 \\
\hline 43 & Pengembangan perikanan penunjang program $\mathrm{P} 2 \mathrm{MBG}$ & $25.000 .000,00$ & $24.940 .000,00$ & 99,76 \\
\hline \multirow[t]{2}{*}{44} & Pelaksanaan gerakan makan ikan (GEMAR) & $50.000 .000,00$ & $49.834 .000,00$ & 99,67 \\
\hline & Jumlah & $2.935 .000 .000,00$ & $2.659 .215 .960,00$ & 91,00 \\
\hline
\end{tabular}

Sumber: Laporan Tahunan Dinas Perikanan dan Kelautan Kab. Brebes, 2008-2009 dan Hasil olahan 2010

Tabel 8. Tahapan Industrialisasi

\begin{tabular}{clcc}
\hline \multirow{2}{*}{ No } & \multirow{2}{*}{ Tahap } & \multicolumn{2}{c}{ Sumbang VA \% terhadap } \\
Sektor Komoditi
\end{tabular}

Tabel 9. Tahapan Proses Industrialisasi di Kabupaten Brebes Tahun 2009

\begin{tabular}{clcl}
\hline No & \multicolumn{1}{c}{ Sektor } & Kontribusi (\%) & \multicolumn{1}{c}{ Tahapan } \\
\hline 1 & Jasa-jasa & 4,74 & Non Industrialisasi \\
& Keuangan, persewaan \& jasa perusahaan & 2,84 & \\
& Bangunan dan konstruksi & 2,14 & \\
& Pertambangan dan penggalian & 1,31 & \\
& Listrik, gas dan air bersih & 0,88 & \\
2 & Industri pengolahan & 12,08 & Menuju proses industrialisasi \\
3 & Perdagangan, hotel, dan restoran & 20,3 & Semi industrialisasi \\
4 & Pertanian & 52,81 & Industri penuh \\
\hline Sumber: Pendapatan Regional Kabupaten Brebes yang telah diolah, 2011 & &
\end{tabular}

Tabel 10. Kecamatan Penghasil Sektor Perikanan Kabupaten Brebes Tahun 2010

\begin{tabular}{|c|c|c|c|c|c|c|}
\hline NO & LAPANGAN USAHA & Losari & Bulakamba & Wanasari & Tanjung & Brebes \\
\hline \multirow[t]{6}{*}{ I. } & PERTANIAN & 1,38 & 0,78 & 1,1 & 1,46 & 1,45 \\
\hline & 1,1 Tanaman Bahan Makanan & 1,07 & 0,97 & 1,01 & 0,48 & 0,4 \\
\hline & 1,2 Tanaman Perkebunan & 1,29 & 0,62 & 0,86 & 0,71 & 0,51 \\
\hline & 1,3 Peternakan dan hasil-hasilnya & 0,34 & 0,11 & 0,1 & 0,05 & 0,14 \\
\hline & 1,4 Kehutanan & 0,07 & 0 & 0 & 0 & 0 \\
\hline & 1,5 Perikanan & 6,81 & 4,46 & 0,18 & 2,54 & 0,1 \\
\hline \multirow[t]{2}{*}{ II. } & PERTAMBANGAN DAN PENGGALIAN & 0,24 & 0 & 0 & 3,89 & 3,06 \\
\hline & 2,1 Penggalian & 0,98 & 0 & 2,28 & 0 & 0,01 \\
\hline
\end{tabular}


III. INDUSTRI PENGOLAHAN

3,1 Makanan, Minuman \& Tembakau

3,2 Tekstil, Barang kulit \& alas kaki

3,3 Barang Kayu dan Hasil hutan lainnya

3,4 Kertas dan Barang Cetakan

3,5 Pupuk, Kimia \& Barang dr karet

3,6 Semen \& Barang lain bukan logam

3,7 Logam Dasar Besi dan Baja

3,8 Alat Angkutan, Mesin \& Peralatan

3,9 Barang lainnya

IV. LISTRIK, GAS, DAN AIR BERSIH

4,1 Listrik

4,2 Air bersih

V. BANGUNAN

VI. PERDAGANGAN, HOTEL, DAN RESTORAN

6,1 Perdagangan besar dan Eceran

6,2 Hotel

6,3 RestorN

VII. PENGANGKUTAN DAN KOMUNIKASI

7,1 Pengangkutan

- Angkutan Rel

- Angkutan Jalan Raya

- Jasa Penunjang Angkutan

7,2 Komunikasi

- Pos dan Telekomunikasi

- Jasa Penunjang Komunikasi

VIII. KEUANGAN, PERSEWAAN, \&JASA PERUSH

0,23
0,08
0,15

0,15

0,06

0,21

0,08

0,2

0

0
0,08

0

0

0

1,12
0,39

0,38

0

1,3

0,96

1,22

1,54

0,13

0,13

1,41

1,01

1,71

0

1,1

1,21

1,06

0,97

1,07

\begin{tabular}{cccc}
$\mathbf{0 , 5 8}$ & $\mathbf{1 , 5 1}$ & $\mathbf{0 , 2 4}$ & $\mathbf{0 , 1}$ \\
0,76 & 0,14 & 1,31 & 0,7 \\
0,89 & 0,21 & 1,54 & 0,59 \\
0,34 & 0,12 & 0,83 & 0,5 \\
1,03 & 0,23 & 1,1 & 1,32 \\
0,55 & 0,17 & 1,77 & 1,23 \\
0,91 & 0,25 & 1,05 & 1,25 \\
0 & 0 & 0 & 0 \\
7,5 & 7,2 & 0 & 0 \\
0,55 & 0,17 & 1,74 & 1,24 \\
0 & 0 & 0 & 0 \\
0 & 0 & 0 & 6,37 \\
0 & 0 & 0 & 7,41 \\
2,63 & 1,19 & 0,28 & 0,27 \\
0,72 & 1,13 & 0,17 & 0,25 \\
1,11 & 1,78 & 2,22 & 2,31 \\
3,52 & 0 & 0 & 4,69 \\
1,38 & 1,15 & 1,7 & 1,62 \\
$\mathbf{2 , 1 5}$ & 0,54 & 0,17 & 0,83 \\
& & & \\
0,61 & - & 0,66 & 3,5 \\
0,59 & 1,25 & 1,02 & 1,74 \\
0,72 & 2,6 & 4,83 & 0,68 \\
& & & \\
0,23 & 0,76 & 1,63 & 4,17 \\
0,23 & 0,76 & 1,63 & 4,17 \\
2,55 & 0,78 & 0,84 & 1,55 \\
0,53 & 0,82 & 0,74 & 1,8 \\
0,34 & 0,66 & 1,19 & 1,62 \\
0 & 0 & 0 & 0 \\
0,95 & 1,27 & 0,57 & 0,87 \\
0,2 & 0,79 & 0,76 & 4,17 \\
2,13 & 0,62 & 1,44 & 0,65 \\
0,61 & 1,38 & 0,62 & 1,15 \\
0 & 0 & 0 & - \\
0,5 & 0,53 & 0,98 & 1,85 \\
1,15 & 0 & 0 & 4,14 \\
0,88 & 0,28 & 0,28 & 1,65 \\
\hline & & & \\
0 & & &
\end{tabular}

Sumber : Pendapatan Regional Kabupaten Brebes Tahun 2010, yang telah diolah

Tabel 11. Kondisi optimis Biaya Budidaya Rumput Laut per Tahun (1 Ha) Kabupaten Brebes Tahun 2011

\begin{tabular}{|c|c|c|c|c|c|c|c|}
\hline NO & URAIAN & JUMLAH & SATUAN & VOLUME & HARGA/TAHUN & TOTAL & TOTAL HARGA \\
\hline 1 & BIAYA INVESTASI & & & & & & \\
\hline a & Sewa Lahan (1Ha) & 1.000 & per meter & 10 & 2.000.000/Tahun & 20.000 .000 .000 & \\
\hline $\mathrm{b}$ & Biaya Peralatan & 10.000 & per meter & 1 & 1.000.000/Tahun & 10.000 .000 .000 & \\
\hline c & Biaya Rehab & 1.000 & per meter & 1 & 1.000 .000 & 1.000 .000 .000 & \\
\hline \multirow[t]{2}{*}{$d$} & Biaya Depresiasi & 1 & $\mathrm{Ha}$ & 1 & & 18.348 .500 & \\
\hline & & & & & & & 31.018 .348 .500 \\
\hline 2 & BIAYA PRODUKSI & & & & & & \\
\hline a & Bibit rumput laut & 1.500 & $\mathrm{Rp} / 5$ meter & 1 & $1500 \mathrm{~kg}$ & 4.500 .000 .000 & \\
\hline $\mathrm{b}$ & Pupuk dan obat-obatan & 10.000 & Rp/per meter & 1 & 1.000 .000 & 10.000 .000 .000 & \\
\hline c & $\begin{array}{l}\text { Biaya tenaga kerja ( } 3 \text { bulan) } \\
\text { Biaya tenaga panen ( } 5\end{array}$ & 25 & orang/hari & 90 & 15000/hari & 33.750 .000 & \\
\hline \multirow[t]{2}{*}{ d } & orang) & 25 & orang $/ \mathrm{kg}$ & 1000 & 22500 (per Kg) & 337.500 .000 & \\
\hline & & & TOTAL INVE & & & & $\begin{array}{r}14.871 .250 .000 \\
\quad \mathbf{4 5 . 8 7 1 . 2 5 0 . 0 0 0}\end{array}$ \\
\hline
\end{tabular}

Tabel 12. Kondisi Pesimis Biaya Budidaya Rumput Laut per Tahun (1 Ha) Kabupaten Brebes Tahun 2011

\begin{tabular}{|c|c|c|c|c|c|c|c|}
\hline No & Uraian & Unit & Satuan & Jumlah & Biaya & Total & Total Harga \\
\hline 1 & BIAYA INVESTASI & & & & & & \\
\hline $\mathrm{a}$ & Sewa Lahan $(1 \mathrm{Ha})$ & 1000 & per meter & 10 & 500.000 & 5.000 .000 .000 & \\
\hline$b$ & Biaya peralatan & 10.000 & per meter & 1 & 500.000 & 5.000 .000 .000 & \\
\hline $\mathrm{C}$ & Biaya rehab & 1.000 & per meter & 1 & 250.000 & 250.000 .000 & \\
\hline \multirow[t]{2}{*}{$d$} & Biaya Depresiasi & 1 & $\mathrm{Ha}$ & 1 & & 7.110 .400 & \\
\hline & & & & & & & 10.257 .110 .400 \\
\hline 2 & BIAYA PRODUKSI & & & & & & \\
\hline $\mathrm{a}$ & Bibit rumput laut & 1.000 & rupiah/5 meter & 2000 & 1200 & 2.400 .000 .000 & \\
\hline $\mathrm{b}$ & Pupuk dan obat-obatan & 1.000 & per meter & 1 & 500.000 & 5.000 .000 .000 & \\
\hline
\end{tabular}




$\begin{array}{lllccrr}\text { c } & \text { Biaya tenaga kerja (3 bulan) } & 15 & \text { orang/hari } & 90 & 10.000 & 13.500 .000 \\ \text { d } & \text { Biaya tenaga panen (5 orang) } & 10 & \text { orang/kg } & 500 & 22.500 & 112.500 .000\end{array}$

TOTAL INVESTASI

Tabel 13. Penerimaan Budidaya Rumput Laut Kondisi Optimis per Tahun (1 Ha) Kabupaten Brebes Tahun 2011

\begin{tabular}{ccccccc}
\hline NO & URAIAN & UNIT & SATUAN & JUMLAH & HARGA & TOTAL \\
\hline 1 & HASIL PRODUKSI & & & & & \\
& Rumput laut basah & 1.500 & Kg/5 meter & 22.500 & 3.500 & 157.500 .000 .000 \\
b & Rumput laut kering & 1.500 & Kg/5 meter & 22.500 & 7.000 & 315.000 .000 .000 \\
& & TOTAL PENERIMAAN & & & $\mathbf{4 7 2 . 5 0 0 . 0 0 0 . 0 0 0}$ \\
\hline
\end{tabular}

Sumber : Data sekunder yang diolah, 2011

Tabel 14. Penerimaan Budidaya Rumput Laut Kondisi Pesimis per Tahun (1 Ha) Kabupaten Brebes Tahun 2011

\begin{tabular}{ccccccc}
\hline NO & URAIAN & UNIT & SATUAN & JUMLAH & HARGA & TOTAL \\
\hline 1 & HASIL PRODUKSI & & & & & \\
a & Rumput laut basah & 1.200 & Kg/5 meter & 10.000 & 1.000 & 112.500 .000 .000 \\
b & Rumput laut kering & 750 & Kg/5 meter & 15.000 & 2.500 & 225.000 .000 .000 \\
& & TOTAL PENERIMAAN & & & 337.500 .000 .000 \\
\hline
\end{tabular}

Sumber : Data Sekunder yang diolah, 2011

Tabel 15. Kelayakan Finansial Budidaya Rumput Laut Kondisi Pesimis per Tahun (1 Ha) Kabupaten Brebes Tahun 2011

\begin{tabular}{|c|c|c|c|c|}
\hline NO & URAIAN & MAXIMUM & & MINIMUM \\
\hline 1 & Nilai Investasi & $\begin{array}{ll}\mathrm{Rp} & 45.871 .250 .000\end{array}$ & $\mathrm{Rp}$ & 7.776 .000 .000 \\
\hline 2 & Masa Investasi & 25 Tahun & & 25 Tahun \\
\hline 3 & Cash In Flow & Rp 317.810.803.865 & $\mathrm{Rp}$ & 214.994.952.682 \\
\hline \multirow[t]{4}{*}{4} & Net Present Value (NPV) & & & \\
\hline & a. $D F=10 \%$ & Rp (433.483.235.810) & $\mathrm{Rp}$ & (300.101.104.789) \\
\hline & b. $D F=12 \%$ & Rp 439.257.549.032 & $\mathrm{Rp}$ & (300.349.930.830) \\
\hline & c. $D F=14 \%$ & Rp 438.857 .374 .827 & $\mathrm{Rp}$ & (300.543.425.709) \\
\hline 5 & IRR & $29 \%$ & & $29 \%$ \\
\hline \multirow[t]{4}{*}{6} & B/C Rasio & & & \\
\hline & a. $D F=10 \%$ & 0,007 & & 0,005 \\
\hline & b. $D F=12 \%$ & $-0,006$ & & 0,004 \\
\hline & c. $D F=14 \%$ & $-0,004$ & & 0,004 \\
\hline \multirow[t]{4}{*}{7} & Pay Back Periode & & & \\
\hline & a. $\mathrm{DF}=10 \%$ & Layak & & Layak \\
\hline & b. $D F=12 \%$ & Layak & & Layak \\
\hline & c. $\mathrm{DF}=14 \%$ & Layak & & Layak \\
\hline
\end{tabular}

Sumber : data sekunder yang telah diolah, 2011 